\title{
PEMETAAN ANALOGI PADA KONSEP ABSTRAK FISIKA
}

\author{
Nyoto Suseno \\ ${ }^{1}$ Fakultas Keguruan dan Ilmu Pendidikan, Universitas Muhammadiyah Metro \\ email: nyotoseno@yahoo.co.id
}

\begin{abstract}
The research of any where founded majority students have common difficulties in abstract physics concept. The result of observation, lecturers have problem in teaching implementation of abstract concepts on physics learning. The objective of this research is to find out the ways how to overcome this problem. The research place of physics education programs and senior high school. The data are colected by quetionere, observation and interview. The lecturer behavior to making out this case is use of analogy to make concrete a abstract concept. This action is true, because the analogies are dynamic tools that facilitate understanding, rather than representations of the correct and static explanations. Using analogies not only promoted profound understanding of abstract concept, but also helped students overcome their misconceptions. However used analogy in teaching not yet planed with seriousness, analogy used spontanously with the result that less optimal. By planing and selecting right analogy, the role of analogy can be achieved the optimal result. Therefore, it is important to maping analogies of abstract consepts on physics learning.
\end{abstract}

Keywords: maping analogies, abstract concept, and physics learning

\section{PENDAhuluaN}

Terdapat dua tipe konsep ilmiah, yaitu konsep faktual dan konsep teoretis. Konsep keadaan materi seperti padat, cair, dan gas adalah konsep faktual, karena contoh aktualnya ada di lingkungan sekitar dan mudah untuk diamati. Konsep seperti atom, elektron, arus listrik, dan sejenisnya tidak ditemukan contoh nyatanya di lingkungan, dan juga tidak dapat diungkapkan dari persepsi terhadap suatu objek, kejadian, atau situasi. Makna konsep tersebut datang dari imajinasi ilmuan, yang hanya dapat dijelaskan secara teoritis, sehingga dinamakan sebagai konsep teoretis atau pada tulisan ini disebut konsep abstrak. Untuk menjelaskan konsep faktual mungkin tidak sulit bagi guru, karena banyak contoh di lingkungan, namun untuk menjelaskan konsep abstrak (teoretis) cukup sulit dilakukan, karena tidak ada contoh nyatanya pada lingkungan belajar peserta didik.

Pemahaman konsep abstrak fisika memerlukan proses berpikir tingkat tinggi. Peserta didik umumnya mempelajari konsep abstrak dengan menggunakan alat praktikum yang hanya mampu menunjukkan gejala makro, lalu direpresentasikan dengan analisis matematis tanpa dapat mengetahui makna fisis dari gejala yang abstrak tersebut. Hal ini sebagai penyebab kesulitan peserta didik dalam mempelajari konsep abstrak fisika. Karena itu perlu suatu cara atau pendekatan yang tepat untuk mengatasi masalah tersebut, dan salah satu solusi yang memungkinkan dan sering digunakan oleh seorang guru adalah dengan menggunakan analogi.

Analogi dalam ilmu bahasa adalah persamaan atau persesuaian antar dua bentuk. Analogi diartikan sebagai kesepadanan antar bentuk yang menjadi dasar terjadinya bentuk lain. Duit (1989) mendefinisikan analogi sebagai persamaan atau kemiripan dari dua domain. Degeng 
(1989) mendefinisikan analogi sebagai gambaran persamaan antara pengetahuan baru dengan pengetahuan yang telah dikenal. Gentner (1983) mendefinisikan analogi sebagai suatu peta pengetahuan dari satu domain ke domain lain yang meperlihatkan suatu sistem hubungan, dimana apa yang dimiliki oleh domain dasar juga dimiliki oleh domain target, dengan analogi seseorang dapat belajar mulai dari suatu domain yang dikenal untuk mempelajari domain lain melalui kaitan analogi. Kaper dan Geodhart (Boersma, 2005) mendefinisikan analogi sebagai pemetaan satu lawan satu antar aspek yang ada dalam domain yang telah dikenal dengan domain yang hendak dipelajari.

Pierce (Lawson, 1993) menyebutkan berpikir analogi sebagai peminjaman (abduction). Menggunakan analogi berarti meminjam ide lama dan mengaplikasikan ke dalam situasi baru untuk mendapatkan kejelasan konsep baru. Glynn et al. (1989) mengemukakan bahwa analogi sering berperan penting dalam berbagai penemuan ilmiah, yakni sebagai sumber inspirasi. Contohnya, Priestley berpikir secara analogi saat ia menemukan hukum gaya listrik. Ia menganalogikan gaya listrik dengan hukum Newton tentang gravitasi. Dalam hukum Newton dinyatakan bahwa garvitasi antara dua benda berbanding terbalik dengan jarak kedua benda tersebut. Berdasarkan hukum Newton tersebut, Priestley berspekulasi bahwa gaya listrik antara dua benda bermuata juga berbanding terbalik dengan jarak kuadrat dari kedua benda tersebut.

Webb (1985) dan Glynn at al. (1989) mengatakan bahwa analogi merupakan jembatan konseptual yang membantu siswa dalam memahami konsep konsep baru. Sebagai ilustrasi siswa tidak dapat melihat atom secara langsung, tidak dapat melihat sifat-sifat atom, tetapi mereka dapat melihat atau mempunyai pengalaman langsung tentang bola, dengan berbagai ukuran. Jadi dengan mengatakan bahwa "atom dalam beberapa hal adalah seperti sebuah bola yang sangat kecil", mungkin memberikan pengertian atau gambaran kepada siswa mengenai atom.

Hasil penelitian tentang penggunaan analogi (Chiu and Lin, 2005; Olive, 2005; Padolefsky dan Finkelstein, 2006) menunjukkan bahwa penggunaan analogi dapat meningkatkan hasil pembelajaran dan dapat mengatasi kesalahan konsep. Suseno (2010) menemukan bahwa penggunaan analogi yang direncanakan dapat meningkatkan penguasaan konsep dalam perkuliahan listrik magnet. Analogi adalah alat representasi untuk memahami sesuatu yang abstrak atau belum diketahui (sebagai domain target), dengan menggunakan pengetahuan lain yang telah dimiliki peserta didik (sebagai domain dasar) berdasarkan kesemilaran.

Pengetahuan dan pengalaman baru bagi seseorang mungkin akan terasa aneh jika tidak relevan dan terkait dengan pengetahuan dan pengalaman yang sudah dimilikinya. Dalam mempelajari sesuatu pengetahuan baru akan lebih bermakna jika dihubungkan dan disesuaikan dengan pengetahuan yang sudah dimiliki. Misalnya dalam menyampaikan materi tentang "kerja mata manusia", agar materi baru itu mudah dipahami oleh siswa maka guru hendaknya mengaitkan materi pelajaran itu dengan materi kajian lain yang telah dikenal siswa. Dalam hal ini misalnya guru menganalogikan "mata manusia" dengan "kamera". Cara berpikir yang demikian dinamakan sebagai berpikir analogi. Berpikir analogi merupakan suatu alternatif untuk menjadikan situasi baru yang mungkin terasa rumit atau aneh menjadi lebih akrab bagi siswa. Dengan menggunakan analogi fenomena yang abstrak dapat dikonkritkan sehingga siswa terbantu untuk mengerti masalah yang dipelajarinya.

Berdasarkan uraian di atas, maka penting untuk dilakukan pemetaan analogi 
dalam fisika terhadap konsep abstrak (sebagai domain target) dari konsep konkrit (sebagai domain dasar), dengan analisis dan kajian yang mendalam, sehingga peta analogi tersebut dapat digunakan oleh setiap guru untuk membantu para siswa dalam mempelajari konsep abstrak fisika secara efektif.

\section{METODE PENELITIAN}

Kajian dilakukan melalui observasi lapangan terhadap pelaksanaan pembelajaran konsep fisika yang dilengkapi dengan angket dan wawancara terhadap dosen dan guru yang mengampu pelajaran fisika untuk mendapatkan data primer. Kemudian dilakukan studi literatur terhadap berbagai sumber, seperti: buku, jurnal ilmiah, artikel, laporan penelitian dan sebagainya sebagai data skunder.

Pengolahan data dilakukan secara kualitatif dimulai dari pemeriksaan dan memilih data hasil angket, observasi dan wawancara yang penting keterkaitannya dengan masalah yang dikaji. Data atau informasi tersebut dikelompokkan sesuai aspek kebutuhan dan permasalahannya, lalu diklasifikasi sehingga memudahkan dalam pembacaan, pengkategorian dan analisis. Kemudian dilakukan analisis dengan cara menguraikan dan menghubungkan berbagai aspek untuk mendapatkan berbagai deskripsi permasalahan yang dihadapi dalam pembelajaran konsep fisika. Dari berbagai masalah tersebut kemudian direduksi untuk mendapatkan akar masalah sesusai dengan fokus kajian. Berdasarkan akar masalah yang didapatkan dari analisis data, dikaitkan dan dibandingkan dengan berbagai hasil kajian teori, kemudian dilakukan analisis dan interpretasi untuk menentukan solusi yang tepat dalam mengatasi permasalahan lapangan tersebut berdasarkan berbagai kajian teori dan kondisi lapangan dan terakhir dilakukan suatu ujicoba untuk melihat respon dan efek dari solusi yang digunakan.

\section{HASIL DAN PEMBAHASAN}

\section{a. Hasil Studi Lapangan}

Hasil survei yang dilakukan terhadap dosen fisika, berkaitan dengan karakteristik materi fisika, diperoleh hasil 100\% menyatakan suka mempelajari fisika, sedangkan persepsi terhadap materi fisika antara yang abstrak dan konkrit hampir sama, masing-masing 50\%. Demikian juga antara yang tergolong kompleks dan sederhana juga sebanding. Kesulitan dalam menyampaikan materi fisika adalah pada pembelajaran konsep yang abstrak, dan untuk mengatasi masalah tersebut biasanya menggunakan animasi, gambar, model dan analogi.

Hasil pengamatan lapangan terhadap pelaksanaan pembelajaran konsep abstrak fisika di beberapa LPTK di Indonesia dan di beberapa SMA, ditemukan bahwa dalam setiap pembelajaran fisika muncul penggunaan analogi dalam beberapa penjelasan dosen maupun guru, sebagaimana diungkapkan pada Tabel 1.

Hasil wawancara terhadap dosen dan guru fisika, terungkap bahwa analogi yang mereka gunakan muncul secara tiba-tiba, tanpa direncanakan. Sedangkan hasil wawancara terhadap mahasiswa tentang penggunaan analogi, mengungkapkan bahwa penggunaan contoh konkrit yang diberikan dosen (sebagai analogi), sangat membantu meraka dalam memahami konsep abstrak fisika.

Berdasarkan Tabel 1, jenis analogi ditinjau berdasarkan representasi yang digunakan dapat dibedakan menjadi empat, yaitu: 1) analogi verbal, 2) analogi visual, 3) analogi simbolik, dan 4) analogi gesture. Berdasarkan subtansinya, analogi dapat dikelompokkan menjadi dua jenis, yaitu 1) analogi dalam satu disiplin (satu bidang ilmu), dan 2) analogi non-disiplin (tidak satu bidang ilmu). Sedangkan berdasarkan bentuk korespondensinya ditemukan analogi 
setara dan analogi invers. Pask (2003) membedakan jenis hubungan analogi menjadi dua, yaitu analogi deskripsi (description analogy) yang dalam tulisan ini dikemukakan sebagai conceptual analogy dan analogi dalam cara (mechanism analogy). Berdasarkan data, diperoleh bentuk analogi dalam satu disiplin ditemukan analogi dalam konsep (75\%) dan analogi dalam cara (25\%). Sedangkan untuk analogi yang non disiplin $100 \%$ termasuk jenis analogi dalam hal cara (mechanism analogy). Menurut Pask (2003) analogi dalam cara (mechanism analogy) cenderung kontra produktif, karena itu pada penelitian ini hanya digunakan analogi dalam satu bidang ilmu fisika.

Tabel 1. Data Hasil Observasi Penggunaan

Analogi dalam Pembelajaran Fisika

\begin{tabular}{|c|c|c|c|c|}
\hline No & LPTK/ SMA & \begin{tabular}{|c|} 
Jumlah tatap \\
muka /jumlah \\
jp (waktu)
\end{tabular} & $\begin{array}{c}\text { Pokok } \\
\text { Bahasan }\end{array}$ & Analogi yang Digunakan Dosen (jenis analogi) \\
\hline \multirow[t]{2}{*}{1.} & \multirow{2}{*}{$\begin{array}{l}\text { Prodi } \\
\text { Pendidikan } \\
\text { Fisika LPTK } \\
\text { Negeri di } \\
\text { Bandung }\end{array}$} & \multirow{2}{*}{$\begin{array}{l}2 \text { kali / } \\
4 \text { jam } \\
\text { pelajaran } \\
\text { (200 menit) }\end{array}$} & \begin{tabular}{|l|} 
Bahan \\
Dielektriku \\
$\mathrm{m}$
\end{tabular} & $\begin{array}{l}\text { 1)Jumlah medan polarisasi dianalogikan dengan jumlah } \\
\text { uang yang dibelanjakan (verbal) }\end{array}$ \\
\hline & & & \begin{tabular}{l|} 
Listrik \\
Dinamis
\end{tabular} & $\begin{array}{l}\text { 2) Arus listrik dianalogikan dengan aliran air dalam } \\
\text { selang (visual) }\end{array}$ \\
\hline 2. & $\begin{array}{l}\text { Prodi } \\
\text { Pendidikan } \\
\text { Fisika LPTK } \\
\text { Negeri di } \\
\text { Lampung }\end{array}$ & $\begin{array}{l}1 \text { kali / } \\
3 \text { jam } \\
\text { pelajaran } \\
(150 \text { menit })\end{array}$ & $\begin{array}{l}\text { Listrik } \\
\text { Statis }\end{array}$ & $\begin{array}{l}\text { 1) Fenomena gaya listrik statis dianalogikan dengan } \\
\text { fenomena gaya gravitasi (visual) } \\
\text { 2) Medan listrik di analogikan dengan percepatan } \\
\text { gravitasi (visual) } \\
\text { 3) Medan dianalogikan sebagai raja yang memiliki } \\
\text { pengaruh/ kekuasaan pada suatu daerah di sekitarnya } \\
\text { (verbal) }\end{array}$ \\
\hline \multirow[t]{2}{*}{3.} & \multirow[t]{2}{*}{$\begin{array}{l}\text { Prodi } \\
\text { Pendidikan } \\
\text { Fisika LPTK } \\
\text { swasta di } \\
\text { Lampung }\end{array}$} & \multirow[t]{2}{*}{\begin{tabular}{|l}
2 kali/ \\
2 jam \\
pelajaran \\
$(200$ menit $)$
\end{tabular}} & $\begin{array}{l}\text { Hukum } \\
\text { Ampere }\end{array}$ & $\begin{array}{l}\text { 1) Arah medan pada solenoid dianalogikan dengan kaidah } \\
\text { tangan kanan (gesture) } \\
\text { 2) Curl dianalogikan dengan arah putaran baut (visual) } \\
\text { 3) Medan magnet dianalogikan dengan medan gravitasi } \\
\text { (visual) } \\
\text { 4) Solenoida dianalogikan dengan bentuk batang, dan } \\
\text { toroida dianalogikan dengan kue donat (verbal) }\end{array}$ \\
\hline & & & \begin{tabular}{|l|} 
Spektro- \\
meter massa
\end{tabular} & $\begin{array}{l}\text { 5)Lintasan partikel spektometer massa dianalogikan } \\
\text { dengan lintasan batu yang dilempar mendatar (gesture) } \\
\text { 6) Arah medan dan partikel pada spektrometer massa } \\
\text { dianalogikan dengan kaedah tangan kanan (gesture) }\end{array}$ \\
\hline 4. & $\begin{array}{l}\text { Prodi } \\
\text { Pendidikan } \\
\text { Fisika LPTK } \\
\text { Swasta di } \\
\text { Semarang }\end{array}$ & $\begin{array}{l}1 \text { kali/ } 2 \\
\text { jam } \\
\text { pelajaran } \\
(100 \text { menit })\end{array}$ & $\begin{array}{l}\text { Induksi } \\
\text { Faraday }\end{array}$ & $\begin{array}{l}\text { 1) Kumparan berarus dianalogikan dengan magnet batang } \\
\text { (verbal) } \\
\text { 2)Efek simpangan kecil saat arus diputus, dianalogikan } \\
\text { dengan efek jika hubungan pria dan wanita putus } \\
\text { (verbal) } \\
\text { 3) Kaitan magnet dan listrik dianalogikan dengan } \\
\text { hubungan siang dan malam, atau pria dan wanita } \\
\text { (verbal) } \\
\text { 4)Prinsip kerja generator dianalogikan dengan kipas angin } \\
\text { yang prinsip kerjanya di balik (visual) }\end{array}$ \\
\hline 5. & $\begin{array}{l}\text { SMA Negeri di } \\
\text { Metro } \\
\text { Lampung }\end{array}$ & $\begin{array}{l}1 \mathrm{kali} / 2 \\
\text { jam } \\
\text { pelajaran } \\
(100 \text { menit })\end{array}$ & $\begin{array}{l}\text { Arus dan } \\
\text { tegangan } \\
\text { listrik } \\
\text { searah } \\
\end{array}$ & $\begin{array}{l}\text { 1) Aliran listrik dianalogikan dengan aliran air pada } \\
\text { selang dan tegangan listrik dianalogikan dengan air } \\
\text { pada bak penampung pada ketinggian tertentu }\end{array}$ \\
\hline 6. & $\begin{array}{l}\text { SMA Swasta di } \\
\text { Metro } \\
\text { Lampung }\end{array}$ & $\begin{array}{l}1 \text { kali/ } 2 \text { jam } \\
\text { pelajaran } \\
\text { (100 menit) }\end{array}$ & $\begin{array}{l}\text { Hukum } \\
\text { Bernoulli }\end{array}$ & $\begin{array}{l}\text { 1) Persamaan bernouli dianalogikan dengan hukum } \\
\text { kekekalan energi mekanik dari suatu benda yang } \\
\text { bergerak }\end{array}$ \\
\hline
\end{tabular}




\section{b. Kebutuhan Dosen dan Mahasiswa Calon Guru Fisika}

Hasil kajian teori melaui forum group discussion yang melibatkan dosen dan guru fisika, mendapatkan informasi bahwa materi fisika yang tergolong abstrak antara lain: fisika kuantum, fisika statistik, fisika zat padat dan listrik magnet, serta pada beberapa kajian materi fisika lain seperti gelombang elektromagnetik, teori kinetik gas bahkan pada mekanika juga terdapat konsep yang abstrak, seperti misalnya gaya normal, gaya reaksi, gaya gesek, serta pada konsep fisika lainnya. Dengan demikian, maka dapat dikemukakan bahwa pada berbagai kajian materi fisika terdapat konsep yang abstrak, sehingga diperlukan suatu cara atau strategi untuk merepresentasikan konsep abstrak tersebut agar lebih konkrit dan mudah dipahami.

Hasil survei terhadap mahasiswa pendidikan fisika ditemukan bahwa mereka $100 \%$ menyukai bidang fisika, namun demikian $67 \%$ menyatakan kesulitan dalam memahami konsep fisika dan hanya 33\% yang menyatakan tidak mengalami kesulitan dalam mempelajari dan memahami konsep fisika. Persepsi mahasiswa terhadap karakteristik materi fisika, $53 \%$ bersifat konkrit dan $47 \%$ bersifat abstrak, serta ditinjau dari kompleksitas materi fisika $73 \%$ kompleks dan $27 \%$ sederhana.

Minat terhadap materi fisika mahasiswa juga memiliki kecenderungan, dari hasil survei ditemukan $40 \%$ menyukai konsep mekanika, $27 \%$ menyukai konsep cahaya dan optik, $20 \%$ menyukai konsep listrik magnet, 6,6\% menyukai termodinamika dan $6,4 \%$ menyukai konsep astronomi, sedangkan konsep fisika yang lain tidak muncul sebagai konsep yang diminati. Dasar pertimbangan pemilihan minat dan kesukaan mahasiswa terhadap materi fisika tersebut antara lain adalah karena tingkat kesulitan dan kemanfaatan konsep dalam perkembangan teknologi dan kehidupan sehari-hari.
Kesulitan mahasiswa yang dominan adalah $67 \%$ pada konsep fisika kuantum, 13,3\% konsep fisika zat padat (kristalografi), $13 \%$ konsep listrik magnet, dan 6,7\% konsep termodinamika. Sedangkan konsep yang lain tidak muncul sebagai konsep yang sulit bagi mahasiswa, namun berdasarkan hasil wawancara ditemukan bahwa pada beberapa konsep yang lain mereka juga mengalami kesuliatan. Faktor kesulitan tersebut 67\% menyatakan karena keulitan matematisnya, $20 \%$ karena konsep abstrak dan 13\% karena konsep yang kompleks. Hasil survei mengungkap cara mahasiswa mengatasi masalah kesulitan tersebut adalah $60 \%$ melalui diskusi dan belajar kelompok, 27\% dengan cara membaca dan mencari sumber belajar, dan $13 \%$ dengan cara mengaitkan dengan materi lain yang sederhana atau yang telah diketahui (cara berpikir analogi).

Berdasarkan uraian di atas, maka ditemukan bahwa para dosen mengalami kesulitan dalam menyampaikan konsep abstrak, sedangkan mahasiswa mengalami kesulitan analisis matematis dan memahami konsep abstrak dan kompleks. Untuk mengatasi kesulitan dalam menjelaskan, dosen menggunakan animasi, gambar, model dan analogi. Sedangkan cara mahasiswa mengatasi kesulitan adalah melalui diskusi dengan teman sebaya, mencari sumber bacaan dan menggunakan analogi dengan konsep yang sederhana. Hasil observasi lapangan, ternyata pada setiap pembelajaran konsep abstrak fisika analogi selalu berperan dalam mengatasi kesulitan tersebut. Dengan demikian, maka analogi sangat diperlukan dalam pembelajaran konsep abstrak fisika, analogi dapat memudahkan peserta didik dalam memahami suatu konsep abstrak fisika. Sehingga analogi perlu dikembangkan dalam penyiapan calon guru fisika.

\section{c. Hasil Pengembangan Peta Analogi}

Analogi dikembangkan dalam satu bidang ilmu fisika, dan dalam penelitian ini 
dikembangkan dua jenis analogi, yaitu analogi dalam konsep (conceptual analogy) dan analogi dalam cara (mechanism analogy). Aspek peta analogi yang dikembangkan meliputi kesamaan atau keseuaian analogi, jenis analogi, perbedaan, alasan penggunaan dan batas penggunaannya. Peta analogi yang akan digunakan pada uji coba pembelajaran adalah materi mekanika. Sebelum analogi digunakan, harus dipastikan bahwa peserta didik telah menguasai domain dasar, karena menurut Suseno dan Setiawan (2012) jika domain dasar tidak dikuasai dengan baik, maka proses pembelajaran tidak dapat berjalan dengan baik sesuai yang direncanakan. Karena itu dalam penggunaan peta analogi ini dipilih yang sesuai dan domain dasar telah dikuasi oleh peserta didik, serta dituangkan dalam perencanaan pembelajaran. Peta analogi yang akan digunaka dikemukakan pada Tabel 2

Tabel 2. Pemetaan analogi pada materi mekanika

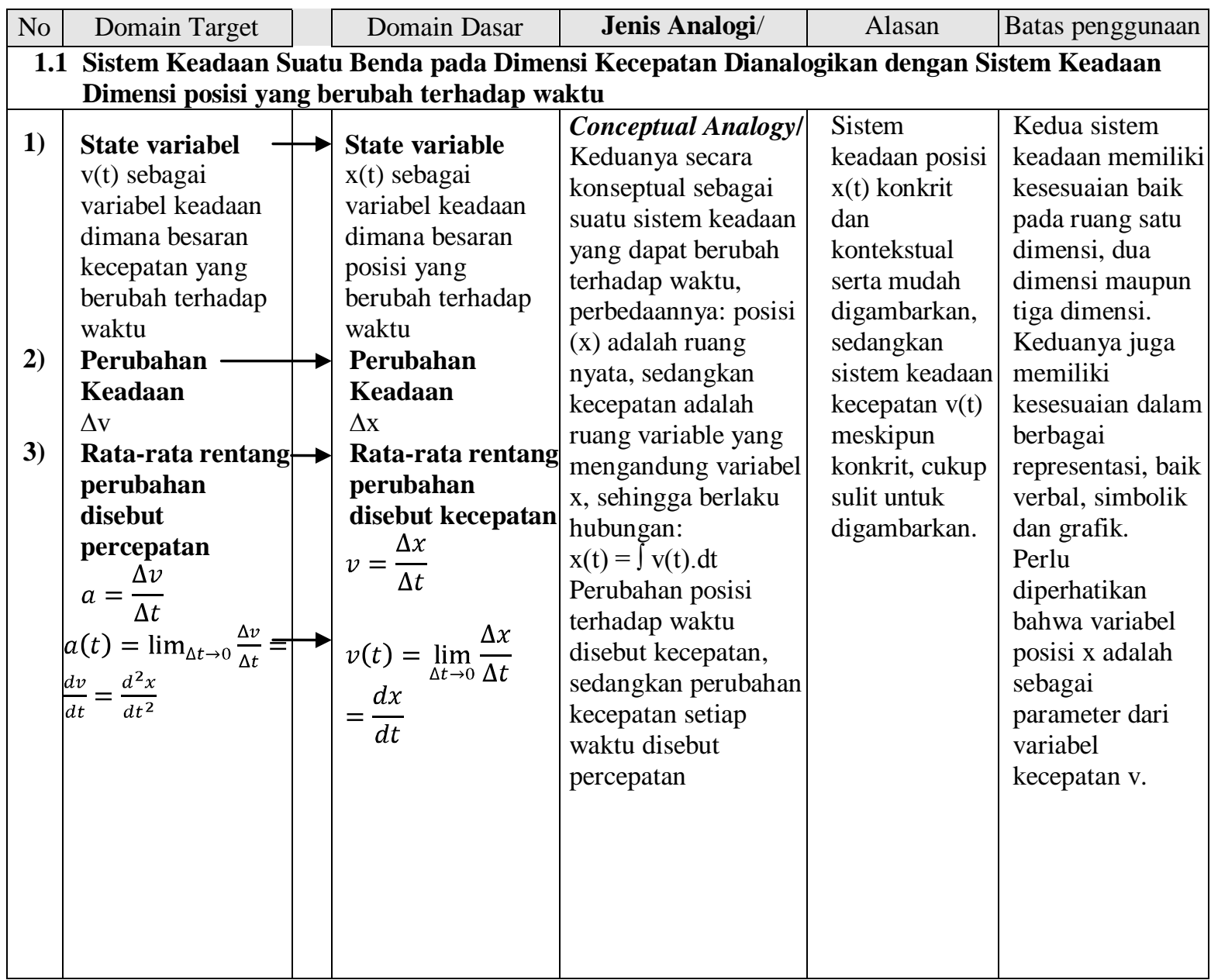




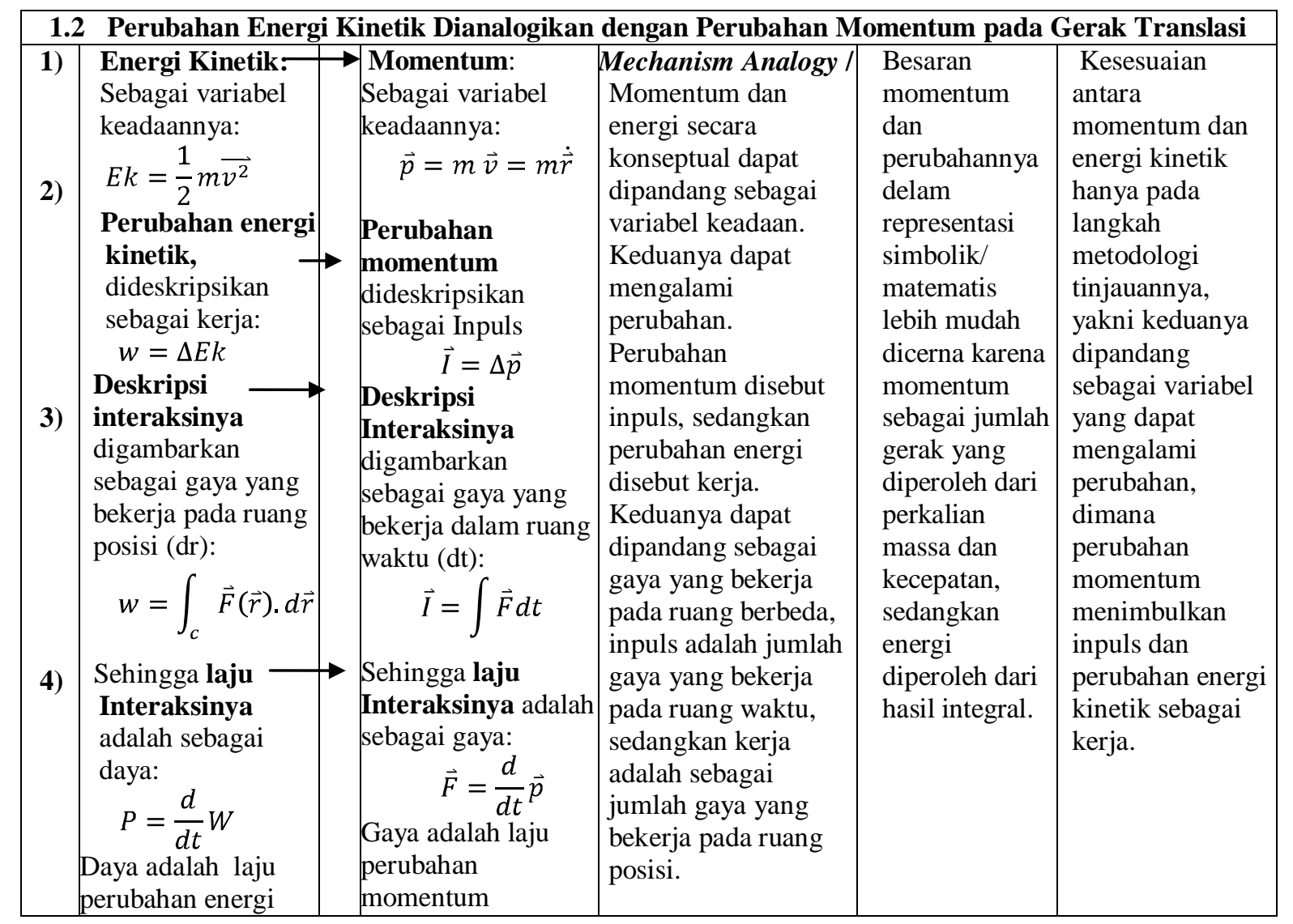

\section{d. Hasil Ujicoba Penggunaan Analogi}

Hasil uji coba penggunaan analogi dalam pembelajaran konsep abstrak fisika dilakukan untuk mendapatkan respon peserta didik dan dosen atau guru (sebagai pengamat). Hasil kuesioner dan wawancara terhadap pelaksanaan uji coba penggunaan analogi dikemukakan pada Tabel 3.

Guna melengkapi data sekaligus sebagai triangulasi, dilakukan wawancara terbuka melalui diskusi sebagai refleksi dari penggunaan analogi dalam pembelajaran konsep abstrak fisika yang diikuti oleh lima observer dalam uji coba, hasilnya sesuai data hasil kuesioner. Pada wawancara atau refleksi juga terungkap bahwa dalam penggunaan analogi perlu direncanakan dengan baik, tidak hanya pada sintaks pembelajaran saja, tetapi juga harus dipilih secara cermat analogi apa yang akan digunakan dalam pembelajaran konsep abstrak fisika.
Berdasarkan temuan tersebut, maka dapat dikemukakan bahwa analogi sangat diperlukan dalam pembelajaran konsep abstrak fisika. Karena itu peran analogi dalam pembelajaran konsep abstrak fisika perlu dioptimalkan dengan cara merencanakan penggunaannya dan memilih analogi yang tepat. Guna membantu para Guru dan Dosen dalam memilih analogi yang tepat dalam pelaksanaan pembelajaran fisika, maka perlu dirancang suatu pemetaan analogi yang sesuai dengan informasi perbedaan dan persamaan yang lengkap, sehingga siap digunakan dalam proses pembelajaran konsep abstrak fisika.

\section{e. Pembahasan}

Hasil penelitian yang terkait dengan efektifitas penggunaan analogi dalam pembelajaran, adalah hasil penelitian Wong (1993) menunjukkan bahwa analogi dapat mempermudah pemahaman siswa terhadap pengetahuan baru. Pada kondisi tertentu, 
penggunaan analogi cukup produktif dalam mengembangkan pemahaman konsep. Hasil penelitian Chiu \& Lin (2005) mengungkap bahwa penggunaan analogi tidak hanya membantu dalam menjelaskan konsep abstrak, tetapi juga membantu siswa dalam memperbaiki kesalahan konsep.

Holyoak dan Thagard (Chin and Lin, 2005) mengemukakan bahwa analogi memiliki empat penggunaan yaitu: penemuan, pengembangan, evaluasi, dan pengungkapan. Menurut Wong (1993) analogi sebagai alat untuk memudahkan pemahaman, memberi representasi dengan benar dan sebagai penjelasan statis. Kaper dan Goedhart (Boersma, 2005) membagi analogi dalam dua katagori, yaitu: (1) analogi sebagai alat untuk menyampaikan informasi baru oleh guru kepada siswa, dan (2) analogi sebagai alat bagi siswa untuk menggambarkan suatu kesimpulan baru. Spiro, Feltovich, Coulson, dan Anderson (Chiu dan Lin, 2005) mengungkapkan bahwa fungsi analogi adalah sebagai: penambahan, koreksi, perubahan (dari analogi sebelumnya), peningkatan (dari analogi sebelumnya), perbesaran (atau pengembangan), pergeseran pandangan, kompetisi, dan urutan contoh.

Berdasarkan uraian di atas, jelaslah bahwa analogi dapat membantu mempermudah pemahaman peserta didik dalam mempelajari konsep abstrak. Duit (1989) mengemukakan tentang keuntungan dan kelemahan penggunaan analogi sebagai berikut, keuntungan penggunaan analogi adalah: (1) berharga (valuable) dalam merubah konsepsi siswa yang keliru, (2) memudahkan siswa dalam memahami konsep abstrak, (3) dapat menvisualisasi konsep yang abstrak, (4) dapat menarik minat dan motivasi siswa, dan (5) dapat mengungkapkan miskonsepsi siswa. Sedangkan kelemahan penggunaan analogi: (1) analogi tidak pernah tepat benar dengan konsep target, (2) jika siswa salah memahami konsep analogi, maka ia akan salah juga memahami konsep target, dan (3) penggunaan analogi secara spontan dalam pembelajaran dapat merugikan siswa.

Glynn et al. (1989) mengungkapkan bahwa tidak ada analogi yang ideal, masingmasing mempunyai keterbatasan, sehingga perlu menggunakan berbagai analogi untuk tujuan yang berbeda. Berdasarkan teori konstruktivisme tentang belajar, disebutkan bahwa belajar itu terjadi bila ada gambaran kesesuaian antara pengetahuan yang akan dipelajari dengan apa yang telah diketahui. Menurut Degeng (1989) agar analogi benarbenar efektif dan dapat memberikan manfaat dalam pembelajaran konsep abstrak, maka pengetahuan analogi hendaknya dicari yang semirip mungkin dengan pengetahuan yang dipelajari.

Berdasarkan beberapa ungkapan dan hasil penelitian di atas, dapat dinyatakan bahwa analogi merupakan suatu alat yang dapat digunakan untuk membantu mempelajari sesuatu yang abstrak atau belum diketahui (domain target) melalui pengetahuan lain yang telah diketahui (domain dasar) melalui kesemilaran atau korespondensi satu lawan satu. Penggunaan analogi dapat meningkatkan penguasaan konsep, serta dapat mengatasi kesalahan konsep. Karena itu perlu dirancang suatu pemetaan analogi yang tepat berdasarkan analisis dan kajian yang mendalam, sehingga diperoleh analogi yang siap digunakan oleh para guru atau dosen dalam pembelajaran konsep abstrak Fisika.

Hasil ujicoba penggunaan analogi menunjukkan bahwa penggunaan analogi yang direncanakan dengan baik akan mendapatkan hasil yang baik. Respon dari peserta didik maupun expert dalam uji coba penggunaan analogi cukup positif, analogi dinilai sangat diperlukan dan dapat membantu dalam menjelaskan konsep abstrak fisika dan tidak menimbulkan kesalahan konsep. 
Tabel 3 Opini Responden terhadap Penggunaan analogi dalam Pembelajaran Konsep Abstrak Fisika

\begin{tabular}{|l|l|l|}
\hline No. & \multicolumn{1}{|c|}{ Responden } & Pendapat \\
\hline 1. & Peserta Didik & $-100 \%$ menyatakan bahwa analogi diperlukan dan sangat \\
& & membantu dalam proses pembelajaran \\
& & $-89,5 \%$ menyatakan bahwa dengan penggunaan analogi tersebut \\
& & mereka paham dengan konsep yang dijelaskan. \\
& & $-100 \%$ menyatakan bahwa cara penggunaan analogi dalam \\
& & pembelajaran sudah cukup baik. \\
\hline 2. & Observer/Penilai & $-100 \%$ menyatakan bahwa analogi diperlukan dan sangat \\
& ahli (Dosen \& & membantu dalam pembelajaran konsep abstrak fisika \\
& Guru) & $-80 \%$ menyatakan bahwa dengan penggunaan analogi, penjelasan \\
& & konsep abstrak menjadi mudah dipahami . \\
& & $-100 \%$ menyatakan bahwa penggunaan analogi dalam \\
& & pembelajaran sudah cukup baik. \\
\hline
\end{tabular}

\section{UCAPAN TERIMAKASIH}

Terimakasih kami ucapkan kepada Ditlitabmas Dikti Kemendikbud yang telah memberikan dana dalam penelitian ini. Ucapan terimakasih juga kami sampaikan Kepada Lembaga Penelitian UM Metro yang telah memfasilitasi dalam pelaksanaan penelitian ini.

\section{KESIMPULAN}

1) Analogi dapat digunakan sebagai alat untuk membantu siswa dalam merepresentasikan atau mengkonkritkan sesuatu yang abstrak, namun dalam penggunaan analogi harus direncanakan dan dipilih analogi yang paling sesuai serta diketahui batas kesamaan dan perbedaannya.

2) Perlu dirancang suatu pemetaan analogi konsep abstrak fisika berdasarkan analisis dan kajian yang mendalam, sehingga diperoleh rumusan analogi yang memuat persamaan dan perbedaannya, serta batasan penggunaan analogi tersebut.

3) Penggunaan analogi dalam proses pembelajaran yang penggunaannya direncanakan dan dipilih dengan baik sangat diperlukan dan dapat membantu dalam menjelaskan konsep abstrak serta tidak menimbulkan kesalahan konsep.

\section{REFERENSI}

(1) Boersma K. et al. (2005). Research and The Quality of Science Education. Netherlands: Springer.

(2) Chiu, M. H. dan Lin, L. W. (2005). "Promoting Fourth Graders' Conceptual Change of Their Understanding of Electric Current via Multiple Analogies". Journal of Research in Science Teaching. 42, (4), 429 - 464.

(3) Degeng, 1. Ny. S. 1989. Ilmu Pengajaran Taksonomi Variabel. Jakarta: P2LPTK Depdikbud.

(4) Diut (1989). "Teachers Use of Analogies in Their Regular Teaching Routines". Journal of Research in Science Education. 19, 291-299.

(5) Duit. R. 1991. "On the Role of Analogies and Metaphors in Learning Science". Science Education. 75, (6), $649-672$.

(6) Gentner, D. 1983. "StructureMapping: A Theoritical Framework for Analogy". Cognitive Science. 7, $155-170$. 
(7) Glynn et al. 1989. Analogical Reasoning and Problem Solving in The Textbooks. New York: Plenum.

(8) Lawson, A.E. (1993). "The Importance of Analogy: A Prelude to the Special Issue". Journal of Research in Science Teaching. 30, (10), 1213 - 1214.

(9) Oliva, J. M. (2005). "What Professional Knowledge Should we as Physics Teachers have about The Use of Analogies?". Journal Physics Teacher Education. 3, (1), 11 - 16.

(10) Podolefsky, N. S. and Finkelstein, N. D. (2006). "Use of Analogy in Learning Physics: The Role of Representation". Physics Review Special Topics, Physics Education Research. 2, (020101), 1 - 10.

(11) Susenon, N. \& Setiawan, A. 2012. Pengembangan Model Pembelajaran Inkuiri Menggunakan Analogi pada
Konsep Rangkaian Listrik Seri dan Paralel. Jurnal Pendidikan dan Pembelajaran (JPP). 19, (2), 205 212.

(12) Suseno, N., Setiawan, A. \& Rustaman, N. Y. (2010). Pembelajaran Menggunakan Analogi dalam Perkuliahan Listrik-Magnet. Disampaikan pada Seminar Nasional Fisika dan Pendidikan Sains di Universitas Sebelas Maret Surakarta pada tanggal 8 Mei 2010.

(13) Webb, M. J. (1985). "Analogies and Their Limitations". Journal of School Science and Mathematics. 85, (8), 645 -650 .

(14) Wong, E.D. (1993). “Understanding the Generative Capacity of Analogies as a Tool for Explanation". Journal of Research in Science Teaching. 30, 1273

1290. 